\title{
THE CHARGE OF THE LIGHT BRIGADE And South Africa's Very Own Pony
}

\section{H.J. (Dick) Usher*}

The story of the cavalry charge which I shall relate might have been forgotten by now had it not been immortalized by Alfred Lord Tennyson in his poem, 'The Charge of the Light Brigade. Two stanzas from that work appear in this article.

The Crimean War (1853-1856) was so named because nearly all the fighting took place in the Crimea, a peninsula north of the Black Sea. Russia was a large country with few seaports. The Black Sea lies to the south of Russia, but part of the shores of the Black Sea belonged to Turkey and the Turks could keep the ships of other nations away from their shores. For this reason Russia planned to take possession of Turkey and offered to divide it, when conquered, with Britain. But Britain was not interested, and also did not want Russia to gain too much power. In the Crimean War the Allies consisted of Turkey, France, Sardinia, and Britain. The war was ended by the Treaty of Paris in 1856.

The Battle of Balaclava was fought on October 25th, 1854, on the plain of Balaclava. Mountains of moderate height rose along the perimeter of the plain, which was divided by a range of small hills, named the Causeway Heights, into two valleys. On the Heights a small number of guns had been placed for defence by the Turks. During the battle the Turks were driven from their positions, and as each gun was captured by the Russians, it was turned on the Allies. The British Heavy Brigade was formed up on the plain together with an infantry regiment, the 93rd Highlanders. A force of four-hundred Russian cavalry charged down upon the Highlanders, who fought back with such effect that in no time they had the Russians fleeing in retreat. The main body of the Russian cavalry at this stage headed for the British Heavy Brigade, under BrigadierGeneral Scarlett, but the engagement lasted for a short while only, and once more the Russians fled. They regained the position of the Heights where the guns captured from the Turks still stood. They found time to unite their forces and to consolidate their position. Apart from their cavalry and artillery, they added to their numbers by bringing up infantry reinforcements as well.

The Light Brigade consisted of the 4th and 13th
Light Dragoons, the 8th and 11th Hussars, and the 17th Lancers, a total of approximately sixhundred men, under Brigadier-General Lord Cardigan. Lord Cardigan received an order that he was to prevent the Russians carrying away certain guns, and somehow he understood that he was meant to make a full frontal attack against the Russian position. Although he knew that it was contrary to all rules of tactics to charge the front of an artillery battery, the order as he understood it was carried out. The charge of the Light Brigade was due to a dreadful mistake, and it is claimed to have happened because of the poor leadership and personal rivalry of two high-ranking British officers, both senior to Lord Cardigan. For a mile-and-a-half the Light Brigade rode through the deadly fire of the Russian guns, and as the Brigade advanced, the Russian rate of fire increased. Close enough six-hundred horsemen took part in that charge, and less than one-third survived.

\section{Someone had blundered. \\ Theirs not to make reply, \\ Theirs not to reason why, \\ Theirs but to do and die, \\ Into the valley of Death \\ Rode the Six Hundred. \\ Flashed all their sabres bare, \\ Flashed as they turned in air \\ Sabring the gunners there, \\ Charging an army, while \\ All the world wondered.}

And to add to that great tragedy, four-hundredand-seventy-five horses lay dead on the battlefield. I have not been able to ascertain whether or not any South Africans were serving with the Light Brigade at that time, but I give you the assurance that a very large number of the faithful beasts that paid with their lives, were South African horses

During the Crimean War the British used South African horses on a very large scale. They were actually known as Cape Horses and I shall relate their history briefly. The horse is not native to Southern Africa, and when the Cape was first settled in 1652, there were no horses to be found. But only specimens of the true quagga, which were related to the zebra but less striped. 
The quagga has since become extinct. There were also the Cape mountain zebra and Burchell's zebra. But horses were imported from Java as early as 1653 . They were of Persian and Arab strain, and horses imported during the next one-hundred years were of the same strain. Old records state that these horses were small but hardy, and of excellent constitution and temperament. In South America there were horses which had originated in Andalusia, Spain. These Andalusian horses had the blood of the Barb strain, which is a breed of North African origin, similar to the Arab. In 1778 a number of these horses were imported from South America. In 1782 eight English Blood stallions were imported along with five Barb-type horses which had been bred in Boston, in the United States. Later importations were mostly of Oriental and Spanish blood, but between 1811 and 1820 Lord Charles Somerset introduced several Thoroughbreds, and the colonists followed this example. From the foregoing what became known as the Cape Horse was bred, and it was this horse which was used by the British on a large scale during the Crimean War.

In 1825 the first Cape Horses reached Basutoland, today known as Lesotho. It is believed that they were captured from marauding Griquas. Basuto labourers working in South Africa were often paid in kind, a much favoured reward for their services being horses, which they took home to Basutoland. There was a demand for high-class stallions and excellent blood-stock entered the territory. So do we see that the Cape Horse was the father of what became known as the Basuto Pony. From about 1860 there was a decline in the horse-breeding industry, due to severe horse-sickness and other setbacks, which was to lead to the Cape Horse virtually diappearing from the scene.

During the nineteenth century the Basuto Pony's fame spread, and ponies were exported to India for military purposes. By the end of the century the Anglo-Boer War spread the fame of the horses throughout the British Empire. Unfortunately the price of this fame was the rapid decline of the type. As early as 1893 the Basutoland authorities tried to save the Basuto Pony type through imports of Arabian and other horses, but their efforts met with little success.

The British forces in South Africa soon discovered that the Basuto Ponies were better horses than their own, and during the course of the war they bought thirty-thousand from the Basuto na- tion. This has immortalised the Basuto Pony and numerous war anecdotes tell of the courage, loyalty and hardiness of these horses in the service of both Boer and Briton. The Basuto Pony often stood just over thirteen hands, and these small animals could cover great distances day after day, carrying eighty kilograms and more in weight. All lived off the veld. They were the most fearless and sure-footed of any known type or breed. It was through the South African War that the Basuto Pony lost its best and largest numbers. The horse never really recovered from the shock and the situation was aggravated by the fact that during World War 1 more than two-thousand ponies were exported to what was then called German South-West Africa, and an unknown number to East Africa. The animals which remained in Basutoland were inferior and factors such as droughts, over-grazing and neglect caused further deterioration.

In 1951 the South African Department of Agriculture bought a nucleus group of Basuto-type ponies and in 1952 started a breeding project at the Nooitgedacht Research Station in the district of Ermelo in the Transvaal. This was not only to save the Basuto Pony from extinction, but also because South Africa needed an indigenous farm and riding horse suited to South African conditions. A stallion, Vonk and six mares were bought from Mr J.A.N. Cloete of Molteno in the Cape Province, and five mares from Mr M.G. Willemse of Memel in the Orange Free State. It is of interest that Mr Cloete's father's stud had achieved fame even before the South African War of 1899-1902. Large-scale inbreeding had already taken place, and for this reason it was decided to use not only the stallion Vonk, but also a Boer Horse stallion (a son of the Cape Horse) and a part-bred Arab stallion to a limited extent. It must be pointed out that Vonk's progeny dominated to such an extent, however, that practically every member of the Nooitgedacht breed today is a descendant of Vonk either on the side of the sire or the dam, or both.

In 1976 the Nooitgedacht Pony was affiliated with the South African Stud Book Association as South Africa's first indigenous pony breed, South Africa's very own pony. Satisfied that its development task had been completed, the Department of Agriculture, (Technical Services) sold all its horses by public auction in March, 1977. The breeding project was now in the hands of the 'breeders' association which had some sixty members in 1979. The ponies also compete annually at the Pretoria Agricultural Show. An inter- 


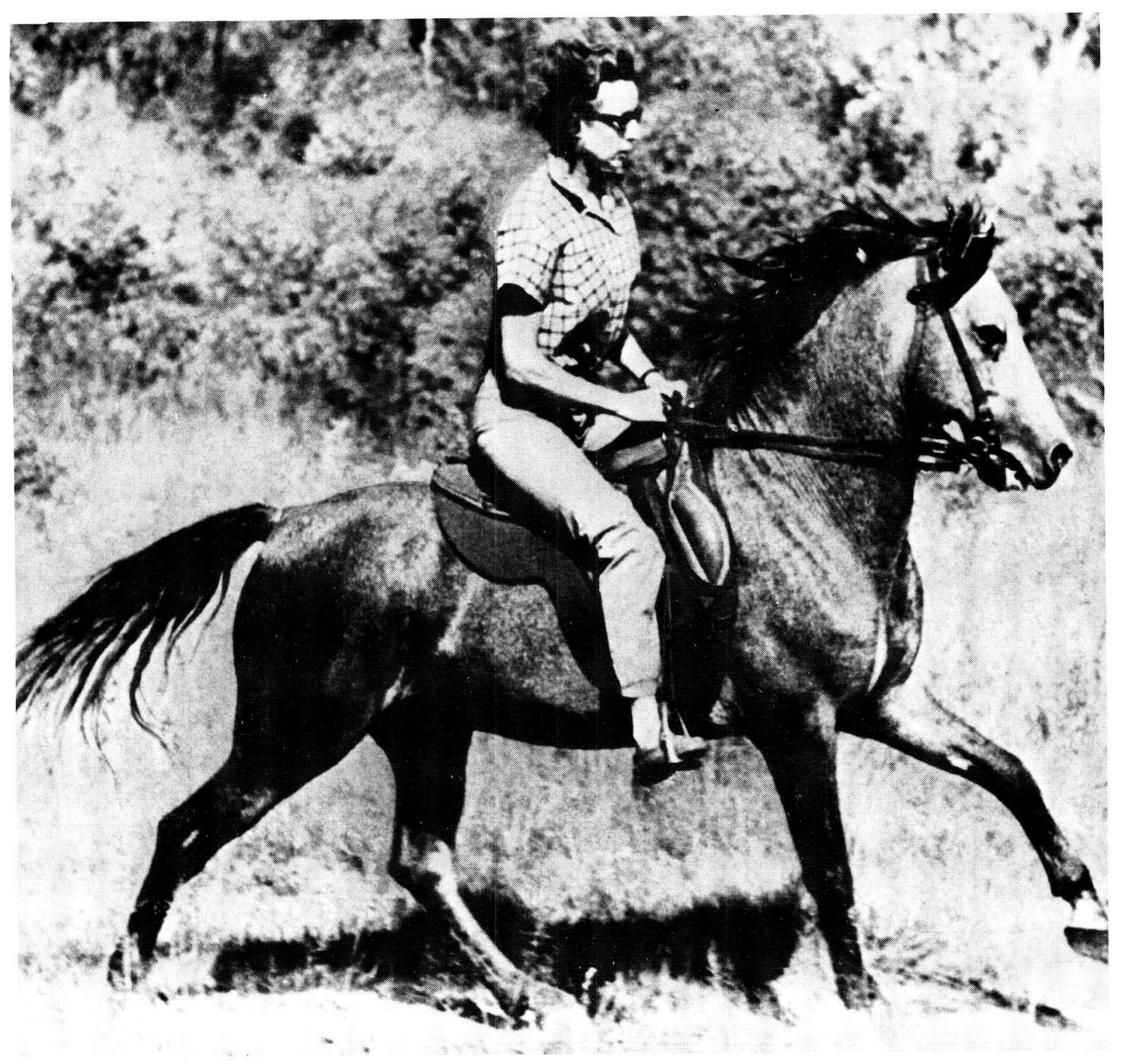

esting description of the Nooitgedacht Pony appeared in the South African Panorama, which wrote of the breed: 'So naturally attracted to man that he will snuggle up immediately after the first introduction. Also lively, and extraordinarily surefooted, intelligent, hardy with exceptional powers of endurance and a comfortable riding gait.' Indeed, the Nooitgedacht Pony is the only true descendant of the Basuto Pony, and takes its place as a pedigree horse breed. It is a living memorial to the fearless Basuto Pony which was once famed beyond South Africa's borders. Beyond all doubt the breeders succeeded in their aim to keep the good qualities of the Basuto
Pony alive and to make a truly South African bred farm, riding and children's horse available to South Africa and its people.

I acknowledge with grateful thanks the assistance unstintingly given me concerning the Nooitgedacht Pony by the Nooitgedacht Research Station, Ermelo. The Director, Animal and Dairy Research Institute at Irene, and the Nooitgedacht Pony Breeders' Society at Menlo Park, Pretoria.

* A freelance writer, Mr Usher is of 1820 British Settler descent. He has a deep interest in matters historical and genealogical. 